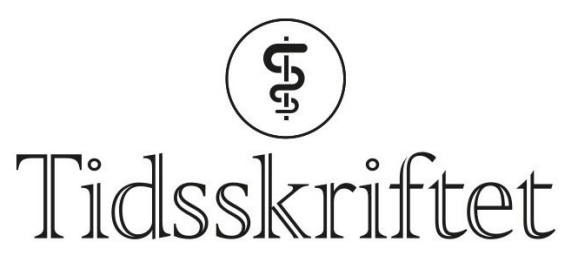

DEN NORSKE LEGEFORENING

\title{
M.K. Worren svarer
}

KOMMENTAR

MARIUS KALSÅS WORREN

Marius Kalsås Worren er lege i spesialisering ved Hjerteavdelingen, Haukeland universitetssjukehus. Ingen oppgitte interessekonflikter.

Takk til Jacob Klafstad for interessant anekdote. Det er godt gjort å huske på den forelesningen i nesten 70 år. Det er beskrevet at avstøpningene kan hostes opp (1). Vi tror symptomene kan være forenlig med plastisk bronkitt. Imidlertid med forbehold om at vi ikke kjenner konsistensen av ekspektoratet og funn ved mikroskopisk undersøkelse.

LITTERATUR:

1. Madsen P, Shah SA, Rubin BK. Plastic bronchitis: new insights and a classification scheme. Paediatr Respir Rev 2005; 6: 292 - 300. [PubMed][CrossRef]

Publisert: 10. desember 2018. Tidsskr Nor Legeforen. DOI: 10.4045/tidsskr.18.0892

(C) Tidsskrift for Den norske legeforening 2020. Lastet ned fra tidsskriftet.no 